Orthopäde $2021 \cdot 50: 455-463$

https://doi.org/10.1007/s00132-020-03956-y

Published online: 4 August 2020

(c) The Author(s) 2020

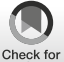

Tobias Schöbel' • Dirk Zajonz ${ }^{1,2}$ - Peter Melcher' - Johannes Lange' Benjamin Fischer ${ }^{2} \cdot$ Christoph-E. Heyde ${ }^{1,2} \cdot$ Andreas Roth $^{1} \cdot$ Mohamed Ghanem ${ }^{1,3}$ 'Department of Orthopaedic Surgery, Traumatology and Plastic Surgery, University of Leipzig Medical Center, Leipzig, Germany

${ }^{2}$ ZESBO-Centre for Research on Musculoskeletal Systems, University of Leipzig, Leipzig, Germany ${ }^{3}$ Arbeitsgemeinschaft Lehre, Deutsche Gesellschaft für Orthopädie und Unfallchirurgie (DGOU), Berlin, Germany

\title{
Podcasts as a teaching tool in orthopaedic surgery
}

\section{Is it beneficial or more an exemption card from attending lectures?}

cial media such as Facebook and Twitter were rated as unsuitable for use in classes [24].

The recording of video podcasts in university teaching has been increasingly used since the beginning of the twentyfirst century [11] either as an additional provision of flexibly retrievable learning materials [16], or as a teaching tool for direct feedback for students when learning clinical skills [10] or basics of medical communication $[9,10]$. Video podcasts are also used as examination tools [9]. In general, the provision of video podcasts is perceived as positive by students [4-6, 8, 18]; however, the effectiveness of video podcasts as teaching tools remains controversial $[5,21,22]$ as does the concern that the provision of online learning material will reduce the number of students attending optional classes [1, $13]$.

The effectiveness of video podcasts as teaching tools has been studied from different angles: Early studies concluded that a classical video podcast that combines the audio or video files recorded during a course with the lecturer's slides can be as effective as traditional lectures $[12,23,25]$. Most studies on the influence of video podcasts on examination results found no significant influence of podcast use on examination results [3, 7, 21, 22]; however, previous studies suggested that the provision of video podcasts does not lead to a loss of lecture attendances [1, 13, 15].

In the winter semester 2018/2019, video podcasts of lectures were recorded for the first time in the main lecture series of orthopaedic medicine at a Central German university and made available to students in a password-protected area (student portal). The aim of this study was to determine the influence of this change in teaching curriculum on examination results, attendance at lectures and the evaluation of courses by students.

Specifically, the study aimed at answering the following questions:

1. Is the provision of video podcasts a reason for students not to attend more or less frequently the facultative lectures of orthopaedics?

2. Which media do the students use to prepare for the examination and when?

3. Does the use of video podcasts have any influence on the examination results of individual students?

Additionally, the use of media preferred by students for examination preparation was analysed to classify the role oflectures in the context of teaching media in times

\begin{tabular}{|ll}
\hline \multicolumn{2}{|l}{ Abbreviations } \\
\hline MC & Multiple choice \\
\hline WS & Winter semester \\
\hline
\end{tabular}

The authors T.Schöbel and D.Zajonz contributed equally to the manuscript.

\section{Availability of data and material}

The datasets used and/or analyzed during this study are available from the corresponding author upon reasonable request. 


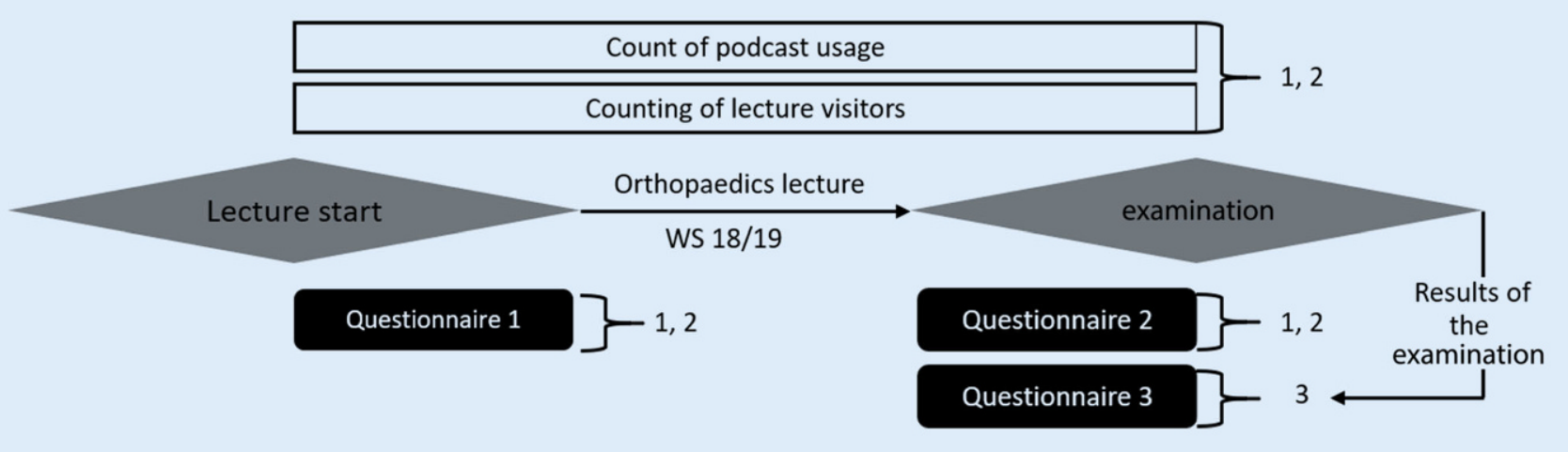

Fig. $1 \Delta$ Data collection in the winter semester (WS) 2018/2019. 1 Influence of online podcasts on lecture attendees. 2 Use of media for examination preparation. 3 Influence of podcasts and other media on the examination result

of digitalization. We hope to be able to make recommendations for teaching in orthopaedics and trauma surgery on the basis of the results.

\section{Methodology}

\section{Technical implementation}

The video podcasts were a classical combination of the lecturers' slides in Powerpoint $^{\text {tw }}$ format (Microsoft, Seattle, WA, USA) and simultaneous audio recording by Camtasia Studio 9 (Techsmith ${ }^{\circledR}$, Okemos, MI, USA) of the lecture. Of the 26 lectures held 21 were recorded as podcasts.

The video podcasts were made available in the password-protected student portal of the medical faculty at the end of the lecture week and were activated for all students of the ninth semester of human medicine until the end of the winter semester 2018/2019. In addition to the 21 lectures, the lecture slides were provided in PDF format (Adobe Inc., San Jose, CA, USA) before or after the respective lecture.

\section{Data collection}

In the winter semester 2018/2019 there were 255 students enrolled in the ninth semester of human medicine, which includes the orthopaedic lectures and examination. Additionally, 51 students of other study semesters participated in the obligatory final examination of orthopaedics and were able to attend the lectures or use the video podcasts.
The data were determined by means of three questionnaires, the continuous counting of lecture attendees, the recording of the number of podcasts retrieved from the student portal, the evaluation of the examination results and the evaluation of the student evaluations of the orthopaedic lecture series over the past 3 years (• Fig. 1 ).

The number of attendees was counted at the beginning of each lecture. The system of the student portal enables retrieval of the video podcast to be recorded as well as the time of the retrieval.

The survey on students' motivation to attend lectures, their attitudes towards the use of video podcasts in teaching, their preferred learning materials and their preparation time for the final examination was carried out in an anonymous questionnaire at the beginning and end of the lecture series and evaluated with EvaSys (Electric Paper Evaluationssysteme GmbH, Lüneburg, Germany).

The first questionnaire was answered at the beginning of the first facultative lecture in the form of a sample of $85 \mathrm{stu}$ dents. It was divided into:

- 3 questions about the previous attendance of lectures and the intention to attend lectures in the upcoming winter semester

- 4 questions about experiences and settings for video podcasts

- 1 free text field for any comments on the use of podcasts in student teaching.

The second questionnaire was distributed at the end of the lecture series as part of a compulsory course and completed by 284 students. It was divided into:

- 2 questions about the actual attendance of lectures in the past winter semester

- 4 questions about students attitude towards video-podcasts

- 2 questions about the possible waiver of the lecture visit by the provision of video podcasts of the lectures and, if applicable, the reasons

- 7 questions about the time of examination preparation and the preferred learning materials (multiple choice).

A third questionnaire was also handed out before the compulsory examination and the student's matriculation number could be voluntarily provided. The results of this questionnaire could then be correlated with the examination results. The questionnaire was completed by 225 students. It was divided into:

- 2 questions about setting up video podcasts

- 1 question about attending lectures in orthopaedics last winter semester

-1 question about the preferred learning materials for examination preparation.

\section{Statistical analysis}

The data obtained in the third questionnaire were correlated with the examination results of the students using the Spearman rank test. The program SPSS (IBM Corp. Released 2016. IBM SPSS Statistics for Windows, Version 24.0. Ar- 
monk, NY, USA) was used and the significance level was fixed at $p<0.05$.

\section{Data protection}

All participating lecturers had consented in writing to the publication of the lecture slides as podcasts. No patient data were published in the lectures. All students completed a declaration of consent to the use of anonymized data, in particular examination results, as part of the survey. In the absence of consent or rejection, the student was not included in the analysis.

\section{Results}

\section{Influence of video podcasts on lecture attendance}

Of the students surveyed at the beginning of the lecture period (questionnaire 1) $79 \%$ stated that they would like to attend more than half of the orthopaedics lectures (- Fig. 2a). In the survey at the end of the lecture series (questionnaire 2) only $15.1 \%$ of the students stated that they had attended more than $50 \%$ of the lectures in orthopaedics (• Fig. 2b). At the beginning of the lecture series $95 \%$ of the students stated that the provision of a podcast was a useful supplement to attending the lectures and $84.8 \%$ of the interviewed students found the provision of a video podcast of the lecture to be a useful alternative to attending lectures (- Fig. 3). At the end of the lecture series $91.2 \%$ of the respondents considered the video podcasts to be a meaningful supplement to attending lectures and $87.7 \%$ a meaningful alternative to attending lectures (- Fig.4). At the end of the lecture series one third of the students surveyed stated that they had used the podcasts in orthopaedics as a supplement to their attendance at the lectures, and half of the students stated that they had used the podcasts as an alternative to their attendance at the lectures (• Fig.4). Of the students $37.2 \%$ stated that they never and $26.8 \%$ stated that they rarely did not attend lectures as a result of podcast provision (• Fig. 5).

The lecture series had an average of 44 visitors per lecture and the podcasts had an average of 78 hits per lecture
(• Fig. 6). Lectures that were recorded as podcasts, but for which no lecture slides were provided in PDF format, received the highest number of hits. Most lecture visitors were counted at the beginning and end of the lecture series (• Fig. 6).

\section{Media use for examination preparation}

With $83.7 \%$, the most popular learning material for examination preparation among the students surveyed was the lecture slides provided by the lecturers in PDF format. This was immediately followed by the online learning tool AMBOSS (AMBOSS GmbH, Cologne, Germany), which was used by $82.3 \%$ of the students for examination preparation. Of the students $60.4 \%$ stated that they had prepared for the examination with the podcasts of the lecture and $30 \%$ of the students stated that they attended the classical lecture to prepare for the examination. Other learning materials (23.3\%) and textbooks (14.8\%) were only used by a few students for examination preparation (• Fig. 7).

Regardless of the learning material $45 \%$ of the students stated that they prepared for the examination in the week before the examination. An exception was the preparation for the examination by attending the lectures: one third of the attendees stated that they were preparing for the final examination earlier at the beginning of the lecture series. The students surveyed stated that they tended to use the media regularly during the lecture series rather than to prepare themselves in irregular intervals for the examination.

The access figures from the student portal showed that $78.1 \%$ of the accesses to the podcasts took place in the week before the examination. In the first week of the lecture series 3\% of the accesses to the lecture podcasts took place (• Fig. 8).

\section{Influence of podcasts and other media on the examination results}

The examination consisted of 30 multiple choice questions with selection of a single answer. The final examination was passed with a minimum of 18 correctly answered questions. The grades were
Hier steht eine Anzeige. 照 Springer 
Orthopäde 2021 · 50:455-463 https://doi.org/10.1007/s00132-020-03956-y

(c) The Author(s) 2020

T. Schöbel · D. Zajonz · P. Melcher · J. Lange · B. Fischer · C. Heyde · A. Roth · M. Ghanem

\section{Podcasts as a teaching tool in orthopaedic surgery. Is it beneficial or more an exemption card from attending lectures?}

\section{Abstract}

Objective. The aim of this study was to evaluate the influence of the introduction of online podcasts as part of the main lecture series in orthopaedics on the number of lecture attendees, the examination results and the assessment of teaching by the students. Additionally, we evaluated the use of other media for examination preparation.

Methodology. At the beginning and end of the lecture series questionnaires were handed out to the students to evaluate their attitudes towards attending lectures, the use of video podcasts and examination preparation. In addition, the number of lecture attendees and podcast usage during the semester were counted and the statements of the students in the evaluation assessments of orthopaedic teaching were evaluated. The examination results were correlated in a statistical analysis with the learning materials provided by the students for examination preparation.

Results. At the end of the lecture series, 284 students stated that they used the lecture podcast about twice as often as attending lectures; however, for the majority of the students the provision of a video podcast was no reason not to attend the lecture. For example, $37.2 \%$ stated that they never and $26.8 \%$ stated that they rarely had not attended the lecture by providing the podcasts. Of the students $91-95 \%$ considered the availability of lecture podcasts to be a rather meaningful or very meaningful supplement to the lecture visit. Students increasingly used digital media to prepare for examinations instead of using traditional analogue methods. None of the learning methods or materials examined showed a statistically significant advantage in examination results.

Conclusion. Students in the age of digitalization use a variety of learning materials and are no longer bound to classical analog teaching methods. The use of online podcasts had no negative impact on examination performance. Most students perceived lecture podcasts as a useful supplement to lecture attendance. The students praised the expansion of the teaching curriculum to include additional digital offers with positive comments in the evaluations, but without achieving an improvement in these student evaluations.

\section{Keywords}

Medical education - Educational technology . Surveys and questionnaires - Webcasts . Students

\section{Podcasts als Lehrmittel in der orthopädischen Chirurgie. Ist es vorteilhaft oder eher eine Freistellungskarte für den Vorlesungsbesuch?}

\section{Zusammenfassung}

Zielsetzung. Ziel dieser Untersuchung war es, den Einfluss der Einführung von OnlinePodcasts im Rahmen der Hauptvorlesungsreihe der Orthopädie auf die Anzahl an Vorlesungsbesuchern, die Prüfungsergebnisse oder die Bewertung der Lehre durch die Studierenden zu evaluieren. Zusätzlich wurde die Nutzung anderer Lehrmedien zur Prüfungsvorbereitung evaluiert.

Methodik. Zu Beginn und zum Ende der Vorlesungsreihe wurden Fragebögen an die Studierenden ausgegeben, um deren Einstellung zum Vorlesungsbesuch, zur Nutzung von Video-Podcasts und zur Prüfungsvorbereitung zu evaluieren. Des Weiteren wurden die Vorlesungsbesucher und Podcast-Nutzungen während des Semesters gezählt und die Aussagen der Studierenden in den Evaluationsbewertungen der Lehre in der Orthopädie evaluiert. Die Prüfungsergebnisse wurde in einer statistischen Analyse mit den von den Studierenden angegeben Lernmaterialien zur Prüfungsvorbereitung korreliert.

Ergebnisse. Am Ende der Vorlesungsreihe gaben 284 Studierende an, die VorlesungsPodcasts etwa doppelt so häufig genutzt zu haben wie die Möglichkeit zum Vorlesungsbesuch. Jedoch war die Bereitstellung eines Video-Podcasts für den Großteil der Studierenden kein Grund, die Vorlesung nicht zu besuchen. So gaben $37,2 \%$ an "nie" und $26,8 \%$ "selten“ durch die Bereitstellung der Podcasts auf den Vorlesungsbesuch verzichtet zu haben. Für eine "eher sinnvolle" oder "sehr sinnvolle" Ergänzung zum Vorlesungsbesuch hielten $91-95 \%$ der Studierenden die Verfügbarkeit von Vorlesungs-Podcasts. Die Studierenden verwendeten zur Prüfungsvorbereitung vermehrt digitale Medien anstatt klassischer analoger Methoden. Keine der überprüften Lernmethoden oder -materialien zeigte einen statistisch signifikanten Vorteil in der Prüfungsvorbereitung.

Schlussfolgerung. Studierende im Zeitalter der Digitalisierung benutzen eine Vielzahl von Lernmaterialen und sind nicht mehr an klassische analoge Lehrmethoden gebunden. Der Einsatz von Online-Podcasts hatte keinen negativen Einfluss auf die Prüfungsleistung. Die meisten Studierenden empfinden Vorlesungs-Podcasts als eine sinnvolle Ergänzung zum Vorlesungsbesuch. Die Studierenden honorierten die Erweiterung des Lehrcurriculums um digitale Zusatzangebote mit positiven Kommentaren in den Evaluationen, allerdings ohne eine Verbesserung dieser studentischen Bewertungen zu erreichen.

\section{Schlüsselwörter}

Medizinische Ausbildung • Bildungstechnologie - Umfragen und Fragebögen - Webcasts . Studierende awarded in accordance with the study regulations of the medical faculty. The questions were prepared by the lecturers and the students had $45 \mathrm{~min}$ to answer the examination questions. The students achieved an average grade of 1.5 and all candidate passed the final exam. Of the students 184 achieved grade 1 ( $\geq 90 \%$ correct answers to questions), 95 students grade $2(\geq 80 \%)$ and 27 students grade 3 $(\geq 70 \%)$.
There was no statistically significant correlation between podcast use and the examination results of the students $(r=0.06848 ; p=0.3064)$. Additionally, there was no statistically significant correlation between the exam- 


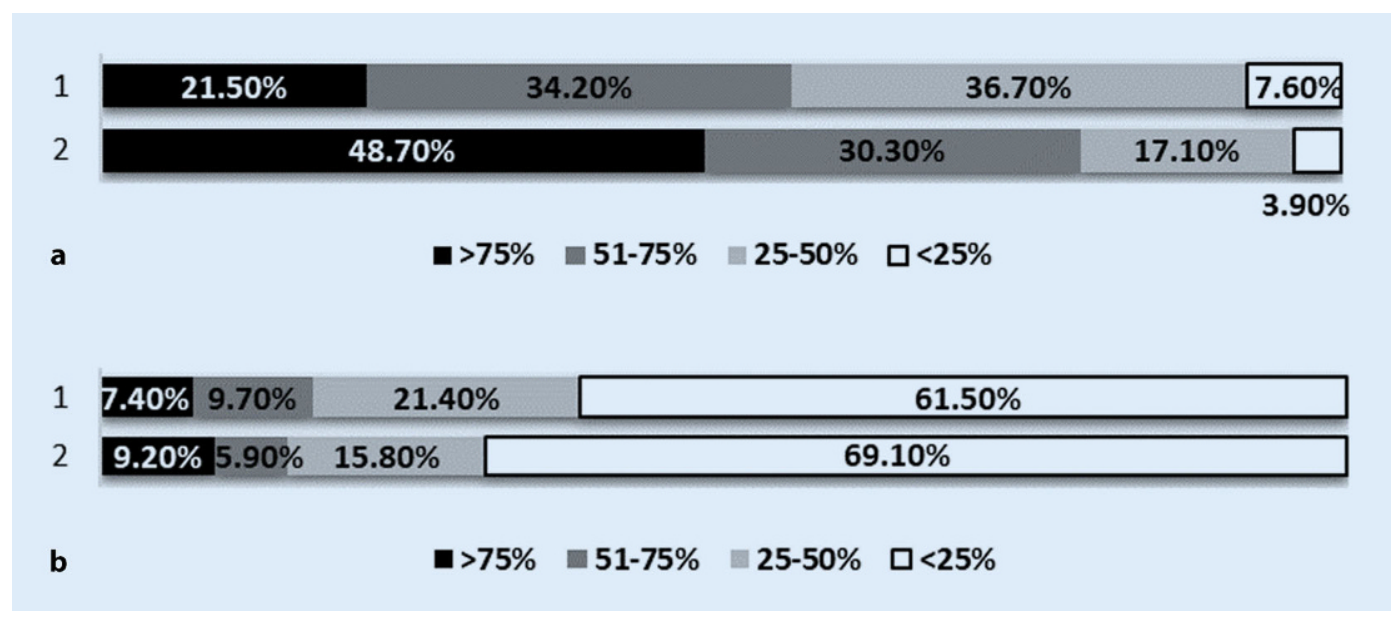

Fig. $2 \Delta$ a Intention of students to attend lectures at the beginning of the lectures: 1 how many lectures will you attend this semester (of the total number of lectures)? ( $n=79$ out of 85 respondents). 2 How many lectures of orthopaedics do you want to attend this semester (of the total number of lectures of orthopaedics)? ( $n=76$ out of 85 respondents). $b$ Self-declaration of the attendance of lectures by the students at the end of the semester: 1 how many lectures did you attend this semester (of the total number of lectures)? ( $n=272$ out of 284 respondents). 2 How many lectures of orthopaedics did you attend this semester (of the total number of lectures of orthopaedics)? ( $n=272$ out of 284 respondents)

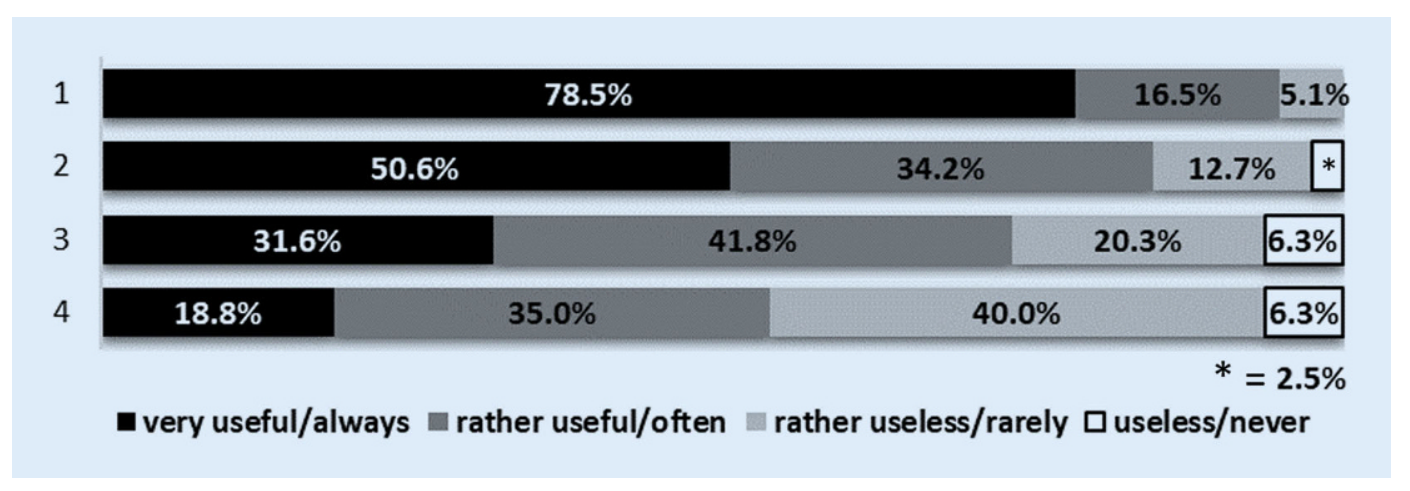

Fig. $3 \Delta$ Assessment of podcast usage by students at the beginning of the lecture series. 1 Do you consider the provision of a podcast to be a useful supplement to attending lectures? ( $n=79$ out of 85 respondents). 2 Do you see the provision of a podcast as a useful alternative to attending lectures? ( $n=79$ out of 85 respondents). 3 Have you ever used podcasts offered for teaching purposes in the past as a supplement to attending lectures? ( $n=79$ out of 85 respondents). 4 Have you ever used podcasts offered in the past as an alternative to attending lectures? ( $n=80$ out of 85 respondents)

ination results and examination preparation through attendance at lectures $(\mathrm{r}=0.05644 ; p=0.3995)$, use of lecture slides $(\mathrm{r}=-0.01413 ; p=0.8331)$, textbooks $(\mathrm{r}=-0.04728 ; \quad p=0.4804)$, AMBOSS $(r=-0.08483 ; p=0.2049)$ or other learning materials $(\mathrm{r}=-0.02999$; $p=0.6553)$. Nor did the frequency of attending lectures $(\mathrm{r}=0.02346 ; p=0.7264)$ (- Fig. 9a) or the frequency of podcast use as an alternative to attending lectures $(\mathrm{r}=0.06797 ; p=0.3101)(\bullet$ Fig. $9 \mathbf{b})$ show any correlation to the examination results.

\section{Discussion}

At the beginning of the lecture series approximately $80 \%$ of a sample of 85 students (questionnaire 1) wanted to attend more than half of the orthopaedics lectures (- Fig. 2a); however, only $15.1 \%$ of the students surveyed at the end of the lecture series (questionnaire 2) stated that they had attended more than $50 \%$ of the orthopaedics lectures ( $\mathbf{0}$ Fig. $\mathbf{2 b}$ ). This self-assessment is in line with our count of the number of lecture attendees during the lecture series, which was $14.4 \%$ with an average of 44 attendees to the lectures out of 306 students surveyed. We assume that the discrepancy between the declaration of intent of the students and the actual attendance of the lecture results from our research setting: The first questionnaire was handed out during the facultative first lecture, which was presumably attended by students who were more interested in the subject and had an affinity for the lecture. The second questionnaire was handed out before the obligatory final orthopaedics examination, in which all students for the corresponding semester had to participate.

The video podcasts were used about twice as often as the lecture visit for examination preparation ( $\bullet$ Fig.7), this assessment of the students was confirmed by our counts of lecture attendees and pod- 


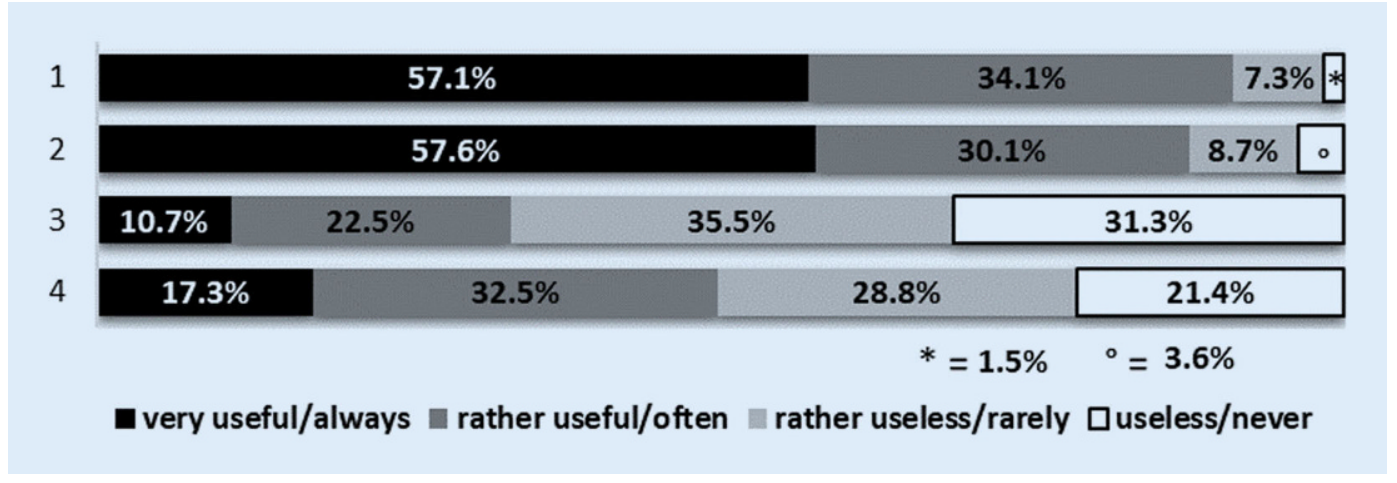

Fig. $4 \Delta$ Assessment of podcast usage by students at the end of the lecture series. 1 Doyou consider the provision of a podcast in the orthopaedics lecture to be a useful supplement to attending the lecture? ( $n=273$ out of 284 respondents). 2 Do you see the provision of a podcast in the orthopaedics lecture as a useful alternative to attending the lecture? ( $n=276$ out of 284 respondents). 3 How often have you used the podcasts offered in orthopaedics as a supplement to attending lectures? $(n=262$ out of 284 respondents). 4 How often have you used the podcasts offered in orthopaedics as an alternative to attending lectures? ( $n=271$ out of 284 respondents)

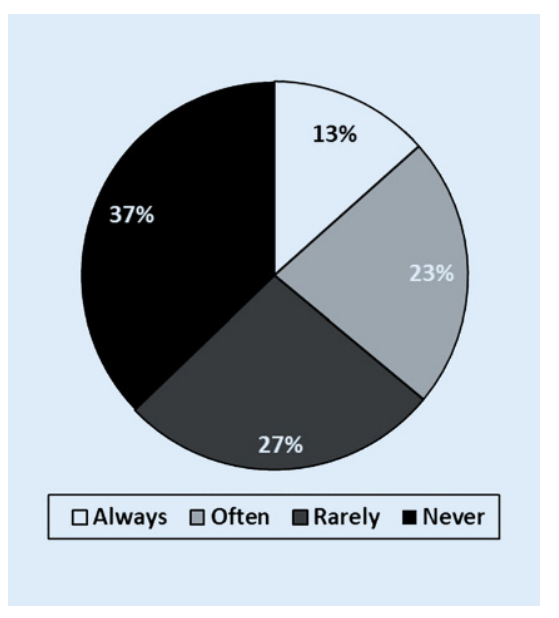

Fig. $5 \Delta$ Students' assessment of the question: how often haveyou avoided attending as a result of podcast provision?

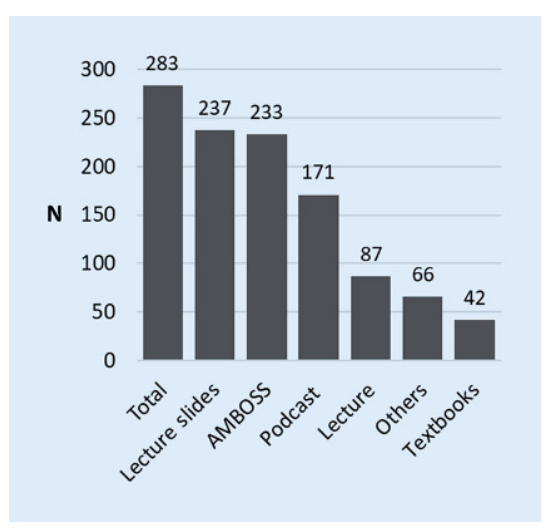

Fig. $7 \Delta$ Number of students who prepared for the examination with a specific learning material (multiple answers possible, $n=283$ out of 284 respondents)

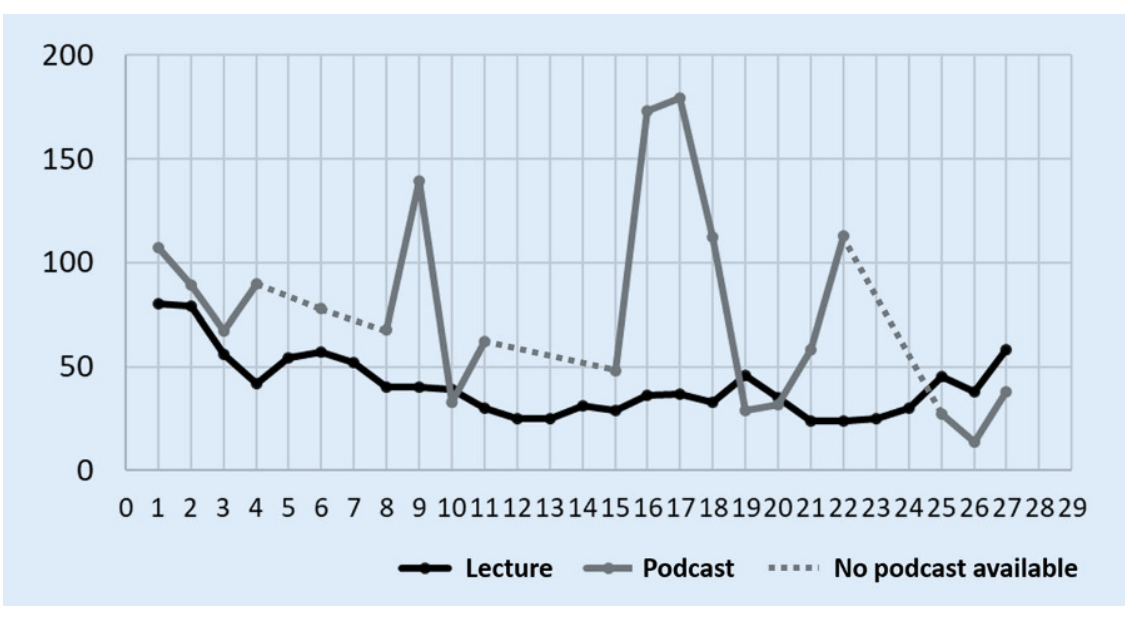

Fig. $6 \Delta$ Number of students present in the lecture and number of accesses to the respective lecture podcasts. X-axis: number of lecture and $y$-axis: number of students

cast users (- Fig. 6). It should be noted that the use of the podcast offer does not exclude attending lectures: $10.7 \%$ of the students surveyed stated that they had always used the podcast and $22.5 \%$ frequently as a supplement to attending lectures (• Fig. 4). Additionally, based on our survey design it could not be excluded that some students watched individual podcasts more than one time or did not watch the podcasts completely.

Only $13 \%$ of the students surveyed answered the concrete question of how often they had given up attending lectures due to the provision of a podcasts, with always, while $23 \%$ said they had done so frequently (• Fig. 5). This observation coincides with previous studies which suggest that the provision of video podcasts does not lead to a heavy loss of lecture visits $[1,13,15]$.

Mattick et al. compared the number of students attending facultative telemedical courses and courses with a lecturer present in 2003/2004. They found no statistically significant difference between the numbers of participants for both groups. Interestingly, Mattick et al. also described the trend observed by us that as courses progressed, fewer students participated in facultative courses with a lecturer present [13]. Later, during a 3year observation period (2004-2006), Billings-Gagliardi and Mazor observed the participation behaviour of students at the University of Massachusetts Medical School, with at least $95 \%$ of the optional courses recorded and the ma- 


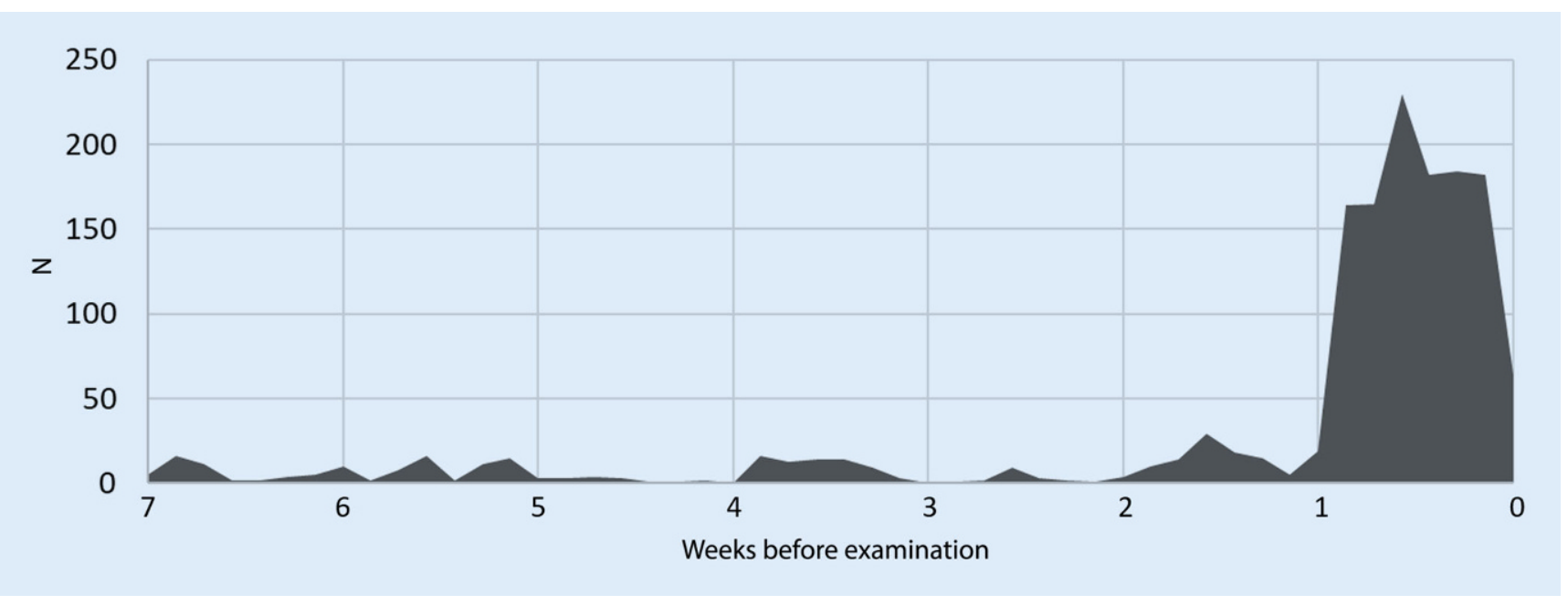

Fig. $8 \Delta X$-axis: weeks to exam and y-axis: number of accesses to lectures from the student portal

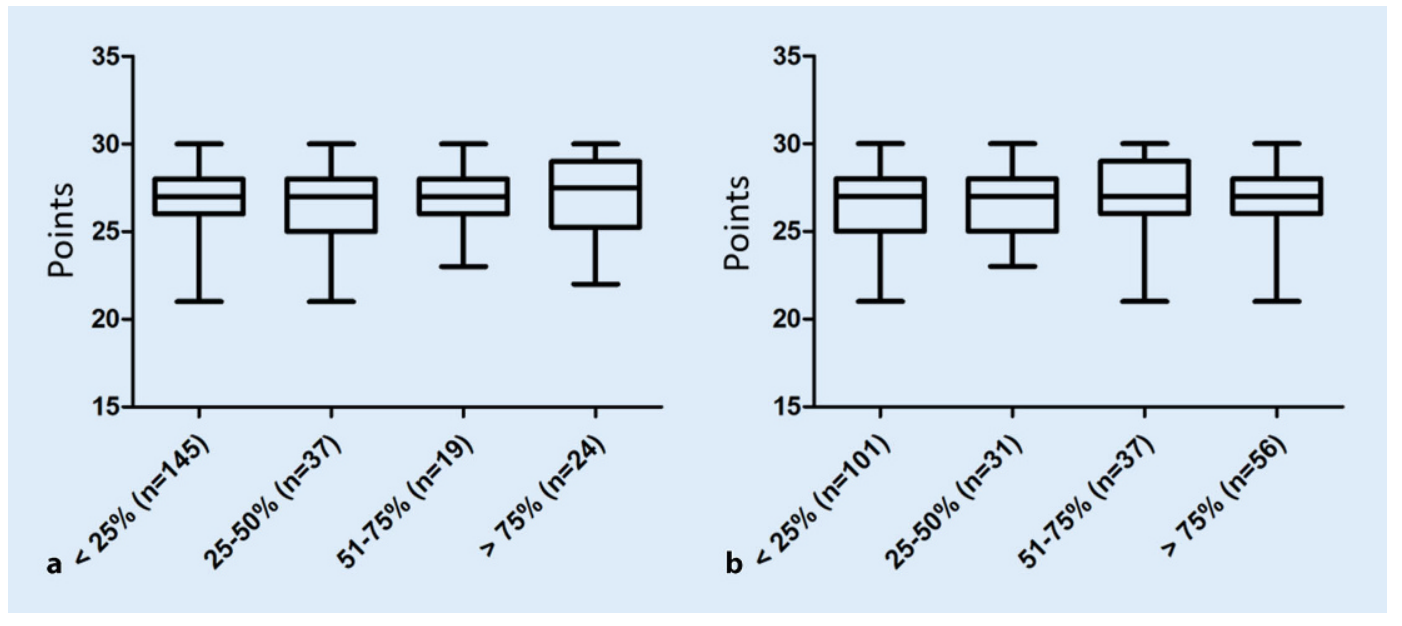

Fig. $9<$ Boxplots of the achieved points in the final examination ( $\mathrm{Y}$-axis) depending on a the frequency of the students' attendance at the lectures (X-axis) and b the frequency of the use of an online podcast as an alternative to the attendance at the lectures (X-axis)

terial made available online for viewing or downloading. In an open question 197 students justified their decision to attend individual courses or to stay away from them. Of these students $90 \%$ stated that the availability of electronic learning materials had no influence on their decision to attend or stay away from events. The remaining $10 \%$ indicated that the availability of electronic teaching materials had contributed more to participation in the courses concerned [1]. These results are consistent with our observations that $91-95 \%$ of students consider the availability of lecture podcasts to be a meaningful complement to lecture attendance (- Figs. 3 and 4 ).

According to Kuhn et al. almost all medical students [11] make intensive use of classical digital media such as PDF files and PowerPoint ${ }^{\circledR}$ presentations. At the same time, these classical digital media represent the only format that is established throughout Germany as part of medical studies [19]. In addition, a large number of students now use webbased knowledge and examination platforms for efficient examination preparation [11]. This statement is in line with our findings, showing a clear preference of the students for examination preparation with digitally available learning materials, such as lecture slides, webbased knowledge and examination platforms (AMBOSS) and video podcasts, coincides with classical analoguelearning options through attendance at lectures or textbooks (• Fig. 7).

There are several studies on the influence of video podcasts on medical examination results [3, 7, 21, 22]. Brockfeld et al. compared the results of 205 students in a $301 \mathrm{MC}$ questionnaire in 2014, where 1 group followed a 41 -h course with a lecturer present and the other group followed the 41-h course as a video. The first group answered $78.3 \%$ of the questions in the subsequent MC test correctly, the second group $78.6 \%$ [3]. In our study, those students who used podcasts to prepare for the final examination answered $89.8 \%$ of the questions correctly on average, and those who prepared without podcasts answered $89.0 \%$ correctly on average. Schreiber et al. came to similar conclusions: 100 students were randomized to attend either a lecture with a lecturer present or watch a video podcast on two clinical topics and then examined both groups with a MC questionnaire. The lecture groups answered $90.2 \%$ of the questions correctly on average, the podcast groups $87.8 \%$ without being able to 
find a statistically significant difference [21]. Davis et al. also found no significant difference in the increase in knowledge between a lecture group and a podcast group on the same medical topic in a similarly designed experimental setup with 229 medical students [7]. An exception is the study by McNulty et al. in which the frequency of podcast use by students was correlated with their course grades: Interestingly, the group of students who had used the fewest video podcasts for preparation had significantly better results than the group of students who had used the video podcast most intensively [15]. The authors justified their observation with the fact that the frequency of use of video podcasts seemed to be higher among students who had problems understanding the topic. Another study by the same research group showed that more frequent use of Internet-based learning materials by students was associated with better examination results [14]. In a study by Rizzolo et al. those students in the examinations who relied the least on Internet-based media for examination preparation scored worst [20].

In the final evaluation of the orthopaedics lecture series, the students gave positive feedback throughout for the provision of online podcasts; however the thematic overlapping of lecture topics, an overloading of individual topics and a missing common theme during the lecture series were criticized. The statements of our students in the free text responses corresponded with the observations of Schreiber et al. who in their previously described experimental set-up had the students evaluate both the quality of the lecture and the online podcasts. The presentation and content quality of the podcasts were consistently rated somewhat worse than that of the lectures; however, the students praised the possibility of flexible learning over time with an online podcast and the ability to pause the podcast, repeat specific sections or the whole podcast [21].

Ultimately, the quality of the lectures in terms of content, an interdisciplinary structure and the lecturers' lecturing skills seem to have been decisive for the students' assessment.
From the perspective of the lecturers, a critical aspect of the provision of online podcasts as part of a lecture series which has to be discussed, are data protection aspects. The use of patient-related data and images must be made anonymously and with the written consent of the parties involved. Patients participating in the lectures for demonstration purposes must sign a consent form or, if necessary, be removed from the lecture transcript. A lack of personnel and technical support [24], uncertainties in dealing with legal aspects of the online availability of lecture materials and the associated increased workload are still existing obstacles in the digitalization of such courses.

\section{Limitations}

A limitation of our investigation is that not all lectures in orthopaedics could be provided as podcasts and that not all lectures were provided with PDF lecture slides. A conclusion as to whether the absence of individual podcasts or lecture slides had an influence on the relevant lecture topic in the examination results was not possible due to the test setting.

Furthermore, the average very good results in the final examination make it more difficult to investigate the influence of the learning materials or learning times used on the examination results. It might have been possible to find correlations between these influencing factors and the individual examination results if there had been a greater disparity.

Based on the given data, another limitation lies in the fact that no exact comparison between the changes of students' motivation to participate in a lecture was possible. The first questionnaire was answered during the facultative first lecture with possibly more interested students whereas the second and third questionnaires were taken before the compulsory examination, with all students of the semester participating. This possibly caused a bias and increased the difficulties in comparing the data. A follow-up of all questionnaires was not possible due to the anonymous data collection for the first and second questionnaires.

Finally, in order to determine whether the provision of video podcasts would reduce the number of students attending the lectures, it would be desirable to count the number of attendees in the previous years of the orthopaedicslectures in order to objectify the statements made by the students.

\section{Conclusion}

Students in the age of digitalization use a variety of learning materials and are no longer tied to classical analogue teaching methods. They are increasingly using digital media such as online lecture slides, web-based knowledge and examination platforms and online podcasts to prepare for examinations instead of traditional analogue methods, such as attending lectures or acquiring knowledge through textbooks. The use of online podcasts did not have a negative or positive impact on the test performance.

The provision of video podcasts of the main lectures in orthopaedics was no reason for the majority of students not to attend the lecture. For most students, lecture podcasts were a useful supplement to attending lectures, and students praised the expansion of the teaching curriculum to include additional digital offers with positive comments in the evaluations.

\section{Corresponding address}

\section{PD Dr. Dirk Zajonz}

Department of Orthopaedic Surgery,

Traumatology and Plastic Surgery, University of Leipzig Medical Center

Liebigstr. 20, 04103 Leipzig, Germany

dirk.zajonz@medizin.uni-leipzig.de

Acknowledgements. We thank Dr. med. Martin Neef for providing the access numbers from the student portal as well as Alexander Lachky and Matthias Henze for the technical support in the creation of the online podcasts and the evaluation forms.

Funding. Open Access funding provided by Projekt DEAL.

\section{Compliance with ethical guidelines}

Conflict of interest. T. Schöbel, D. Zajonz, P. Melcher, J. Lange, B. Fischer, C.-E. Heyde, A. Roth and M. Ghanem declare that they have no competing interests.

Ethical standards. Due to the survey-based study 
design, no approval by the ethics committee of the University Hospital of Leipzig, Germany was necessary.

Open Access. This article is licensed under a Creative Commons Attribution 4.0 International License, which permits use, sharing, adaptation, distribution and reproduction in any medium or format, as long as you give appropriate credit to the original author(s) and the source, provide a link to the Creative Commons licence, and indicate if changes were made. The images or other third party material in this article are included in the article's Creative Commons licence, unless indicated otherwise in a credit line to the material. If material is not included in the article's Creative Commons licence and your intended use is not permitted by statutory regulation or exceeds the permitted use, you will need to obtain permission directly from the copyright holder. To view a copy of this licence, visit http://creativecommons.org/licenses/by/4.0/.

\section{References}

1. Billings-Gagliardi S, Mazor KM (2007) Student decisions about lecture attendance. Do electronic course materials matter? Acad Med 82(10 Suppl):73-76. https://doi.org/10.1097/ACM. 0b013e31813e651e

2. Bosslet GT, Torke AM, Hickman SE, Terry CL, Helft PR (2011) The patient-doctor relationship and online social networks. Results of a national survey. J Gen Intern Med 26(10):1168-1174. https://doi.org/10. 1007/s11606-011-1761-2

3. Brockfeld T, Müller B, de Laffolie J (2018) Video versus live lecture courses. A comparative evaluation of lecture types and results. Med Educ Online 23(1):1555434. https://doi.org/10.1080/ 10872981.2018.1555434

4. Callas PW, Bertsch TF, Caputo MP, Flynn BS, Doheny-Farina S, Ricci MA (2004) Medical student evaluations of lectures attended in person or from rural sites via interactive videoconferencing. Teach Learn Med 16(1):46-50. https://doi.org/10.1207/ s15328015tIm1601_10

5. Cardall S, Krupat E, Ulrich M (2008) Live lecture versus video-recorded lecture. Are students voting with their feet? Acad Med 83(12):1174-1178. https://doi.org/10.1097/ACM.0b013e31818c6902

6. Copley J (2007) Audio and video podcasts of lectures for campus-based students. Production and evaluation of student use. Innov Educ Teach Int 44(4):387-399. https://doi.org/10.1080/ 14703290701602805

7. Davis J, Crabb S, Rogers E, Zamora J, Khan K (2008) Computer-based teaching is as good as face to face lecture-based teaching of evidence based medicine. A randomized controlled trial. Med Teach 30(3):302-307. https://doi.org/10.1080/ 01421590701784349

8. Harris H, Park S (2008) Educational usages of podcasting. Br J Educ Technol 39(3):548-551. https://doi.org/10.1111/j.1467-8535.2007.00788.

9. Humphris GM, Kaney S (2000) The Objective Structured Video Exam for assessment of communication skills. Med Educ 34(11):939-945

10. Kneebone R, Kidd J, Nestel D, Asvall S, Paraskeva P, Darzi A (2002) An innovative model for teaching and learning clinical procedures. Med Educ 36(7):628-634. https://doi.org/10.1046/j.13652923.2002.01261.x

11. Kuhn S, Frankenhauser S, Tolks D (2018) Digitale Lehr- und Lernangebote in der medizinischen
Ausbildung. Schon am Ziel oder noch am Anfang? Bundesgesundheitsblatt Gesundheitsforschung Gesundheitsschutz 61(2):201-209. https://doi. org/10.1007/s00103-017-2673-z

12. Markova T, Roth LM (2002) E-conferencing for delivery of residency didactics. Acad Med 77(7):748-749

13. Mattick K, Crocker G, Bligh J (2007) Medical student attendance at non-compulsory lectures. Adv Health Sci Educ Theory Pract 12(2):201-210. https://doi.org/10.1007/s10459-005-5492-1

14. McNulty JA, Halama J, Espiritu B (2004) Evaluation of computer-aided instruction in the medical gross anatomy curriculum. Clin Anat 17(1):73-78. https://doi.org/10.1002/ca.10188

15. McNulty JA, Hoyt A, Gruener G, Chandrasekhar A, Espiritu B, Price R, Naheedy R (2009) An analysis of lecture video utilization in undergraduate medical education. Associations with performance in the courses. BMC Med Educ 9:6. https://doi.org/10. 1186/1472-6920-9-6

16. Nieder GL, Nagy F (2002) Analysis of medical students' use of web-based resources for a gross anatomy and embryology course. Clin Anat 15(6):409-418. https://doi.org/10.1002/ca.10067

17. Oblinger D, Oblinger JL (2005) Educating the net generation. EDUCAUSE, Boulder CO

18. Parson V, Reddy P, Wood J, Senior C (2009) Educating an iPod generation. Undergraduate attitudes, experiences and understanding of vodcast and podcast use. Learn Media Technol 34(3):215-228. https://doi.org/10.1080/17439880903141497

19. Persike M, Friedrich J-D (2016) Lernen mit digitalen Medien aus Studierendenperspektive. Berlin: Hochschulforum Digitalisierung http://www.che-ranking.de/downloads/HFD_

AP_Nr_17_Lernen_mit_digitalen_Medien_aus_ Studierendenperspektive.pdf

20. Rizzolo LJ, Aden M, Stewart WB (2002) Correlation of Web usage and exam performance in a human anatomy and development course. Clin Anat 15(5):351-355. https://doi.org/10.1002/ca.10045

21. Schreiber BE, Fukuta J, Gordon F (2010) Live lecture versus video podcast in undergraduate medical education: a randomised controlled trial. BMCMed Educ 10:68. https://doi.org/10.1186/1472-692010-68

22. Solomon DJ, Ferenchick GS, Laird-Fick HS, Kavanaugh K (2004) A randomized trial comparing digital and live lecture formats. BMC Med Educ 4:27.https://doi.org/10.1186/1472-6920-4-27

23. Spickard A, Alrajeh N, Cordray D, Gigante J (2002) Learning about screening using an online or live lecture. Does it matter? J Gen Intern Med 17(7):540-545. https://doi.org/10.1046/j.15251497.2002.10731.x

24. Vogelsang M, Rockenbauch K, Wrigge H, Heinke W, Hempel G (2018) Medical education for "generation Z". Everything online?!- -an analysis of Internet-based media use by teachers in medicine. GMS J Med Educ 35(2):Doc21. https://doi.org/10. 3205/zma001168

25. Wofford MM, Spickard AW, Wofford JL (2001) The computer-based lecture. J Gen Intern Med 16(7):464-467
Springer Medizin Podcast

Medizin für Gesundheitsprofis

Der Podcast von SpringerMedizin.de geht seit Juli 2020 spannenden Fragen aus der Welt der Medizin nach immer freitags erweitert eine neue Folge das bereits bestehende OnlineAngebot.

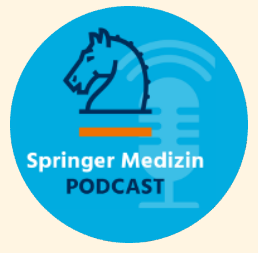

"Mit unserem

Podcast möch-

ten wir all jene ansprechen, die sich auf medizinische Themen in einer, gewissen

Flughöhe' einlassen möchten", erklärt Dr. Erik Heintz, Chefredakteur von SpringerMedizin.de das neue Format. "Gemeint sind damit Menschen, die sich nicht mit medizinischem Halbwissen zufrieden geben und gerne mehr wissen möchten. Daher legen unsere Redakteurinnen und Redakteure in München und Heidelberg vor allem auf den inhaltlichen Anspruch großen Wert. Unter Bezugnahme auf neue Studien, neue Erkenntnisse und praxisrelevantes Wissen bereiten wir jeden Podcast gründlich vor. Die Themen drehen sich um Gesundheit, Krankheit, Diagnostik, Therapie und Prävention, zu denen wir unsere Fachexpertinnen und Fachexperten aus verschiedenen medizinischen Fachgebieten hinzuziehen."

So entstehen abwechslungsreiche Folgen, die sowohl detailliert Leitlinien abarbeiten, der Evidenz von neuen Studienergebnissen auf den Grund gehen, aber auch die Hintergründe zu Erkrankungen und Therapien aufschlüsseln - sodass einerseits die ärztliche Praxis erleichtert und konkrete Tipps für die alltägliche Arbeit vermittelt werden, andererseits aber auch der Horizont über das eigene Fachgebiet hinaus erweitert werden kann.

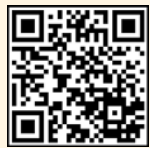

www.springermedizin.de/podcast 